\title{
Effect of different pavements on human thermal comfort conditions
}

\author{
M. Akif IRMAK, ${ }^{1}$ Sevgi YILMAZ, ${ }^{1 *}$ and Doğan DURSUN ${ }^{2}$ \\ ${ }^{1}$ Department of Landscape Architecture, Faculty of Architecture and Design, Ataturk University, 25240, Erzurum, \\ Turkey \\ ${ }^{2}$ Department of City and Regional Planning, Faculty of Architecture and Design, Ataturk University, 25240, \\ Erzurum, Turkey \\ *Corresponding author; email: sevgiy@atauni.edu.tr
}

Received: July 29, 2016; accepted: August 9, 2017

\begin{abstract}
RESUMEN
La isla urbana de calor (ICU) y el confort térmico en espacios exteriores pueden ser afectados por diversos factores como el tamaño del entorno edificado, la proporción de espacios verdes y abiertos y los diferentes tipos de coberturas superficiales (e.g., pasto y coberturas artificiales) en zonas urbanas. De acuerdo con los tipos y estructuras de los pavimentos y materiales de cobertura, que pueden tener efectos en el albedo y el calentamiento superficial, las superficies reflejan la radiación solar o calientan el aire sobre ellas. Los pavimentos que absorben mayor cantidad de radiación solar la pueden convertir en calor, lo cual calienta el aire; esto a su vez eleva la temperatura de las áreas urbanas y provoca incomodidad en los seres humanos. El presente estudio investiga los efectos de diferentes materiales para cobertura de suelo en la intensidad de la ICU. Se consideran nueve tipos de materiales, a saber andesita, granito, basalto, travertino, madera impregnada, tierra, asfalto, polvo de ladrillo y pasto, los cuales fueron analizados en el jardín botánico de Ata en el centro de Erzurum, una ciudad ubicada en Anatolia oriental, Turquía. Las mediciones de temperatura superficial de estos pavimentos se llevaron a cabo durante julio en días soleados, a $150 \mathrm{~cm}$ sobre el suelo y a las 12:00 horas. Se utilizó para ello un termómetro infrarrojo (CEM-DT-8812) y, con el objeto de obtener temperaturas fisiológicamente equivalentes (TFE) para cada tipo de pavimento, los resultados se analizaron con el software RayMan 2.1. Posteriormente se analizaron estadísticamente las puntuaciones de TFE con una prueba de análisis de varianza y las diferencias en las temperaturas medias se evaluaron con la prueba de Fisher de la diferencia menos significativa. Los resultados muestran que los valores medios de TFE variaron de $28.9{ }^{\circ} \mathrm{C}$ para madera impregnada a $25.9{ }^{\circ} \mathrm{C}$ para pasto (una diferencia de $3{ }^{\circ} \mathrm{C}$ ). Las otras puntuaciones fueron las siguientes: $26.1,26.7,27.1,27.5,27.8,28.5$ y $28.5^{\circ} \mathrm{C}$ para travertino, granito, andesita, tierra, polvo de ladrillo, basalto y asfalto, respectivamente. Los resultados analíticos indican que todos los materiales estudiados crean un estrés térmico ligero $\left(23.1-29^{\circ} \mathrm{C}\right)$ acorde con los índices TFE y los niveles de estrés. Sin embargo, el estrés térmico medido para la madera impregnada, el asfalto y el basalto fue mayor que para el resto de los materiales. Se determinó que el pasto, el travertino y los cubos de granito son las coberturas superficiales óptimas, ya que el nivel de estrés térmico que producen es el más cercano al rango de confort térmico $\left(18.1-23.0^{\circ} \mathrm{C}\right)$.
\end{abstract}

\begin{abstract}
The urban heat island (UHI) phenomenon and outdoor human thermal comfort may be affected by several factors such as the size of the built environment, the rate of open and green spaces and different types of ground surface covers (e.g., grass and artificial covers) in urban areas. Depending on the types and structures of the pavement/covering materials, which can have effects on the albedo and surface heating, ground surfaces reflect solar radiation or heat the air above them. Pavements that can absorb more solar radiation may turn it into heat, thus warming the air, which in turn heats urban areas and make them uncomfortable
\end{abstract}


for human beings. The present study investigates the effect of different materials on the UHI intensity by considering nine different types of materials (andesite, granite, basalt, travertine, impregnated wood, soil, asphalt, clinker powder and grass) in the Ata botanical garden located in the city center of Erzurum, in the Eastern Anatolia region of Turkey. Temperature data were measured on clear summer days during the month of July and compared in terms of thermal comfort. All measurements were taken $150 \mathrm{~cm}$ above the ground at 12:00 p.m. by using an infrared thermometer (CEM-DT-8812). In order to estimate the physiologically equivalent temperature (PET) for each soil type, data were analyzed using the RayMan 2.1 software, and the scores were statistically analyzed with analysis of variance (ANOVA). The differences in mean temperatures were evaluated with Fisher's least significant difference (LSD) test. The results showed that mean PET scores ranged between $28.9^{\circ} \mathrm{C}$ for impregnated wood and $25.9^{\circ} \mathrm{C}$ for grass (a difference of $3.0^{\circ} \mathrm{C}$ ), while the other scores were $26.1,26.7,27.1,27.5,27.8,28.5$ and $28.5^{\circ} \mathrm{C}$ for travertine, granite, andesite, soil, clinker powder, basalt, and asphalt, respectively. The analytical results indicated that all the studied materials create a slight heat stress $\left(23.1-29.0^{\circ} \mathrm{C}\right)$ according to their PET indices and their predetermined comfort intervals. However, the levels of heat stress for impregnated wood, asphalt, and basalt were higher than the others. It was determined that grass, travertine and cube granite are optimal surface materials, since they exhibited a level of heat stress that is close to the comfort range $\left(18.1-23.0^{\circ} \mathrm{C}\right)$.

Keywords: Thermal comfort, pavements, PET, urban heat island, outdoor thermal comfort.

\section{Introduction}

A report published by the Department of Economic and Social Affairs of the United Nations (UN, 2012) indicates that $52 \%$ of the world population (3.6 billion people) lives in urban areas, and it is expected that this figure will rise to 6.3 billion by the year 2050 (Aguiar et al., 2014). This projection shows that the rate of urbanized areas will continue to increase in the following 35 years. As the size of urban areas increases, rural and forest areas will be transformed into structured areas, the sizes of green areas will continue to decrease, and covered surfaces will appear over much wider extensions. Following this replacement process of natural vegetated areas with artificial impervious surfaces, temperatures in cities will rise at a high rate.

Those covered lands may hold heat at the surface and radiate it to the surrounding areas, causing the creation of urban heat islands (UHIs) (Oke et al., 1991; Asaeda et al., 1996; Cartalis et al., 2001; Synnefa et al., 2007; Memon et al., 2008; Takebayashi and Moriyama, 2009). Cities have larger paved surfaces that store more heat compared to rural areas, which is one of the main causes of the UHI effect. As indicators of this effect, thermal condition differences between urban and rural areas have been analyzed in many studies (Unger, 1999; Yilmaz et al., 2007a, 2013; Gulyas and Matzarakis, 2009; Ketterer and Matzarakis, 2014; Irmak and Yilmaz, 2015; Rodriguez Algeciras et al., 2016).
The UHI problem negatively affects the quality of life and energy consumption in urban areas. Di Norcia (2008) states that, whether their existence is accepted or denied, changes in climatic elements have reached to a level that can be observed even by people who are not familiar with this kind of issue. As it is emphasized by Lin et al. (2011), the first external impact on individuals is the outdoors temperature, and the most important characteristic of the human body is the ability to adjust to this factor and to the changing climatic conditions. Environmental temperature is the most decisive element in the lifestyle of individuals, but unplanned urban environment and misused materials always force them to this adaptation and decrease their level of comfort. Also, it is known that the negative effects of both UHI and global warming are increasing. In order to reduce heat island effects in urban areas, different thermal comfort studies have been carried out in different parts of the world (Correa et al., 2012; Rupp et al., 2015; Yilmaz et al., 2016). The most important ways to solve this problem are using adequate, well-designed urban planning that places urban environment in the climatic context and contributes to the sustainable development of cities (Rodriguez Algeciras et al., 2016); and employing smart or suitable materials on covered surfaces. The selection of suitable materials can both contribute to healthier, more comfortable urban environments, and to reduce the UHI effect; otherwise, temperature will increase in urban areas and damage the population's health. 
The substitution of natural surfaces (soil, grass) to materials (asphalt, concrete) causes thermal changes due to the energy-storing characteristics of these materials. As a solution, the use of appropriate materials on urban spaces or the replacement of pavements with cooler ones can decrease the surface temperature and help mitigation of the UHI. As is shown in Millstein and Menon (2011), cool roofs and pavements increase the annual average outgoing radiation and reduce the afternoon summertime temperature in urban locations by $0.1-0.5^{\circ} \mathrm{C}$. Similarly, the cooling potential of some pavements was found to be very significant. It is clearly seen that cool pavements decrease temperature in the urban environment (Santamouris, 2013).

As rapid urbanization develops around the world, human thermal comfort conditions will be impacted negatively since paved surfaces have larger effects on urban thermal balance and a high percentage of urban surfaces are covered by pavement. For instance, concrete and asphalt surfaces, which are generally used as pavement materials in the USA and Europe, create high surface temperatures especially during the summer. In the USA, pavements cover almost $29 \%$ of urban areas, increasing their temperature (Santamouris, 2013). In this context, within rapidly increasing global population and urbanization processes, the UHI effect and the level of thermal discomfort will become more acute in the near future. Therefore, the role and effects of urban planning decisions and landscape designs on climate must be emphasized and learned by designers and all related disciplines.

In this process, urban and landscape architects, as well as urban planners have an important role in the solution of these negative effects. Their designs help to reduce some of the temperature-related problems that people face (Lenzholzer and Brown, 2013). Landscape architects are well positioned to reduce these effects through the creation of landscapes, urban planning and site designs that are climate-appropriate. They have increasing awareness of the high impact of material choices in urban climate, as well as the population's health and quality of life. The orientation of buildings, the composition and color of surface materials, and the types and locations of vegetation have major effects on UHIs and microclimates. Due to these direct relationships between urban design and landscape architects, these professionals will have a huge role in reducing or eliminating the heat-related problems that population faces (Lenzholzer and Brown, 2013).

As an example, it is a well-known fact that urban areas, which are designed according to principles of climate-sensitive design, decrease the negative effects of UHI on people (Lenzholzer and Brown, 2013). Due to this direct relationship between urban built environment and urban climate, the effects on temperature changes and thermal comfort of pavement materials used in outdoor places (such as andesite, granite, basalt, travertine, wood, soil, asphalt and grass) should be known and tested before the design process. There are many studies in the literature focused on different types of pavements, the effects of their colors on the UHI, and the effects of different kinds of plants on urban thermal comfort. These studies are mainly concentrated on the issue of energy efficiency, the reduction of UHIs and the creation of urban thermal comfort (Synnefa et al., 2007; Yilmaz et al., 2007b, 2008; Takebayashi and Moriyama, 2009; Leuzinger et al., 2010; Lagouarde et al., 2012; Aguiar et al., 2014). As stated in those studies, pavement materials that emit less heat than others, depending on their reflectivity or structure, must be specified in the design and planning processes. In order to increase the livability in urban areas, the thermal performances of covered surfaces, which depend on their permeability and reflectivity, are crucial.

Asphalt, concrete and similar surfaces in urban environments show high levels of heat emission and radiation compared to soil and vegetation (Yilmaz et al., 2008). These pavements are heated by the sun during the day and absorb this heat. The stored heat is radiated to the surrounding areas at nights. This is one of the reasons that explain why urban areas are usually warmer than rural ones (Jongtanom et al., 2011). For instance, the temperature of asphalt surfaces can reach as high as $70^{\circ} \mathrm{C}$ when exposed to the sun (Bobes-Jesus et al., 2013).

The most effective method for mitigation of the UHI is to increase vegetation in cities. Specifically, the positive influence of trees on urban climate has been the main issue of many studies. Additionally, there are very few cases in the literature about the relationship between different types of pavements and their impacts on UHIs (Santamouris et al., 2011; 
Correa et al., 2012). So, this research will make an empirical contribution to literature on the study area.

The experiments were performed in the city of Erzurum, which is heated by short wave sunlight during the summer months. This is due to its high altitude and the high number of sunny and clear days during this season. Residents feel heat stress in urban areas during the summer months due to the limited vegetation. But, as it is emphasized in the literature, when the appropriate pavement materials are used, the effects of UHIs can be decreased. This could potentially improve the thermal comfort of residents.

The main objective of this study is to establish a relationship between materials and thermal comfort. Also, to create a connection between materials and the UHI, based on their effects on urban environment and temperature. In this context, an attempt is made to show that appropriate pavement materials can reduce the effects of UHIs, thus fostering the emergence of some positive developments in urban areas such as the increase of thermal comfort levels, the reduction of energy consumption, and the creation of sustainable and livable urban environments.

\section{Materials and methods}

\subsection{Study area and climatic conditions}

This study was conducted in the Ata botanical garden, located in the central area of Erzurum in eastern Turkey (Fig. 1). Erzurum has a humid continental climate according to the most widely used Köppen climate classification system (Kottek et al., 2006). This city has also severe winters, warm summers and strong seasonality.

Ata is one of the largest botanical gardens in Turkey with its 35 ha of land. The garden, which is located at 1850 masl, was established in 2006. The prevailing weather conditions of the area change throughout the year. The mean annual air temperature is $5.6^{\circ} \mathrm{C}$ and the annual rainfall is $403 \mathrm{~mm}$. While precipitation is heavy from April to June, dry periods are observed in January, February, August, September, and December (covering 100-150 days). The summer period starts in June and lasts until October, with average maximum temperatures of $26.5-27.1^{\circ} \mathrm{C}$ and minimum temperatures between -13.0 and $-14.2^{\circ} \mathrm{C}$. The warmest month in this area is August, with an average temperature of $27.1{ }^{\circ} \mathrm{C}$.

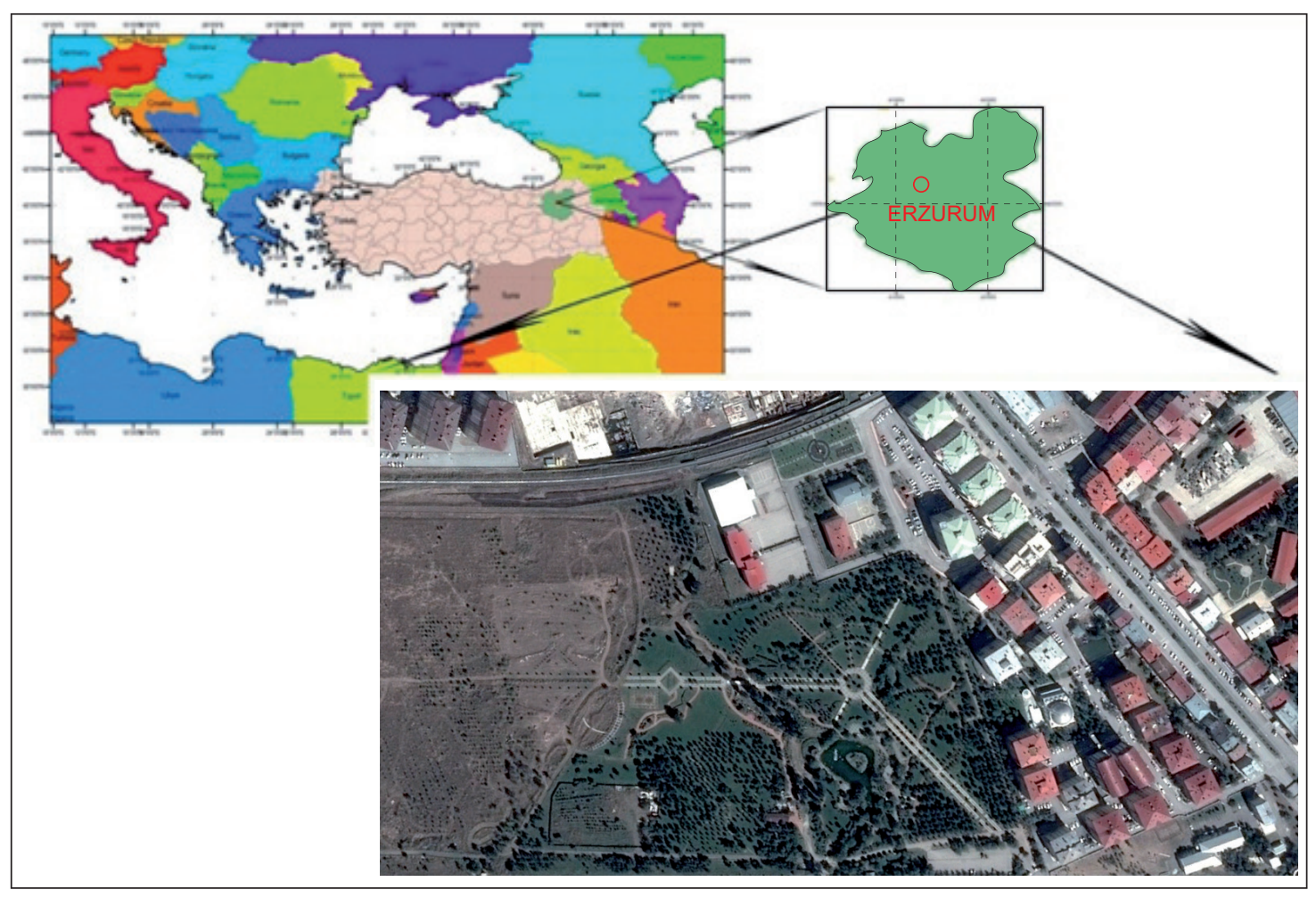

Fig. 1. Location of the study area (Ata botanical garden) at Erzurum, east Turkey ( $\left.39^{\circ} 54^{\prime} \mathrm{N}, 41^{\circ} 15^{\prime} \mathrm{E}\right)$. 
On the other hand, winter conditions prevail during five months from November to March with minimum temperatures between -4.1 and $-14.2{ }^{\circ} \mathrm{C}$. The coldest month is January with an average temperature of $-9.3^{\circ} \mathrm{C}$ (maximum $-4.0^{\circ} \mathrm{C}$ and minimum $-14.2^{\circ} \mathrm{C}$ ). The prevalent wind direction is southwest with a mean annual speed of $2.7 \mathrm{~m} \mathrm{sec}^{-1}$ and the annual sunshine duration is $2504 \mathrm{~h}$.

\subsection{Data collection and analysis}

This study is focused on nine different types of pavements located in the Ata botanical garden, i.e., andesite, granite, basalt, travertine, impregnated wood, soil, asphalt, clinker powder, and grass (Fig. 2). Most landscape architects prefer andesite, granite, basalt and travertine, which are generally used in walking paths, while impregnated wood is designed for resting areas and bridges. Asphalt is commonly used in walking areas, roads and parking lots.
Clinker powder is the material mostly used in running paths. On the other hand, while soil is the natural component of surface covers in urban agricultural areas, green vegetation is often found in the parks. In this context, the impacts of surface temperatures of different pavements and surfaces on thermal comfort are evaluated for summer months.

The nine different types of pavements and surfaces evaluated are commonly used in the city of Erzurum as well as in the whole country. Surface temperature measurements for these materials were done on sunny days during July, which is one of hottest months of the year. Measurements were taken $150 \mathrm{~cm}$ above the ground at 12:00 LT for all pavements, at the same altitude and in similar environmental conditions. Temperatures were measured by using an infrared thermometer (CEM-DT-8812) (Fig. 3) and the findings were used in the analysis (Table I). Additionally, other meteorological data such as surface

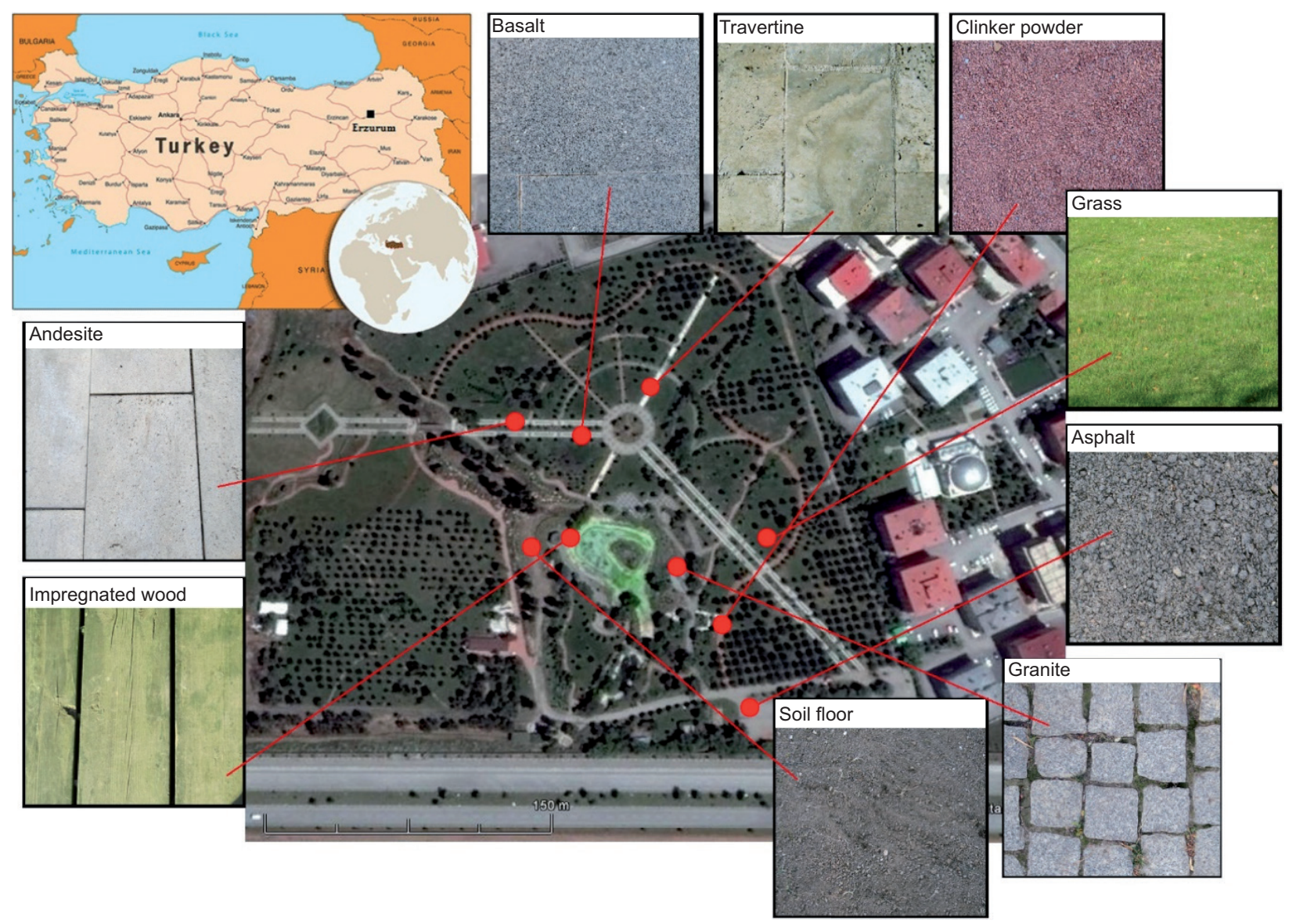

Fig. 2. Types of pavements and surfaces evaluated. 

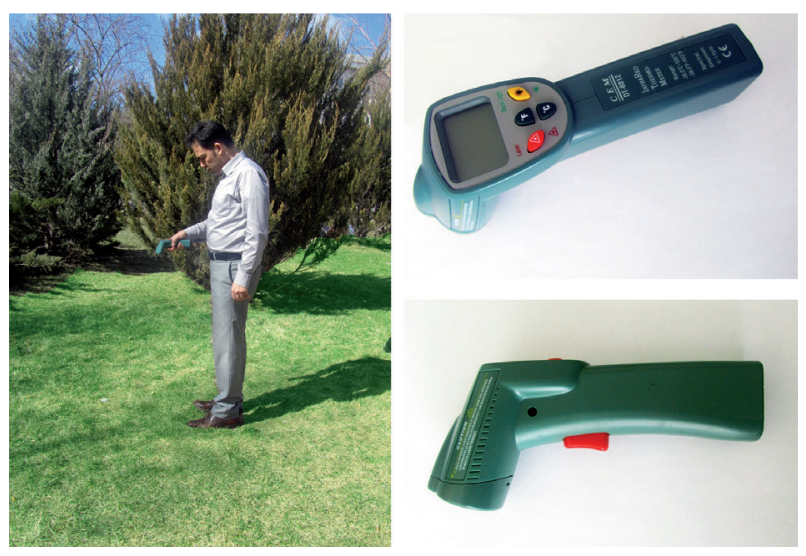

Fig. 3. Measurement method and the tool used (infrared thermometer-CEM-DT-8812).

and air temperature, humidity, wind and cloudiness were used in the study. While the cloudiness data were obtained from the Erzurum meteorological station, the other parameters were measured on-site.

Measurements were analyzed using the physiologically equivalent temperature (PET) index, one of the most commonly used thermal indices (Rodríguez Algeciras et al., 2016). This index defines thermal comfort conditions by using the RayMan Pro 2.1. model, which uses temperature, wind, humidity and cloudiness data to produce PET values. In recent years, several models were developed to estimate the energy balance of the human body in different environments. They all use the data of physical microclimate parameters as well as human biometeorological evaluation of climates. Similarly, in the context of this study, the measurements and meteorological data (air temperature, air humidity, wind speed and clouds) were performed and collected, respectively, for different types of pavements in the botanical garden, with the aim of quantifying thermal comfort. The simulation conditions of the RayMan model in the analysis were defined for a 35-yr-old man who is $1.75 \mathrm{~m}$ tall and weighs $75 \mathrm{~kg}$. Additionally, he has a 0.9 clothing (clo) value, an activity of $80 \mathrm{~W}$, and is in a standing position. After the measurements and data collection regarding air temperature, wind, humidity and cloud cover, the results were transformed to PET scores with the RayMan 2.1 software (Matzarakis et al., 2007, 2010). The obtained PET values were evaluated according to PET index comfort intervals (Table I) and the effects of these ranges on thermal comfort were exposed. These intervals were obtained from the Munich Energy Balance Model for Individuals (MEMI) (Matzarakis and Mayer, 1996), in which those values are determined according to the results of a questionnaire applied on-site in several European cities.

The results were analyzed with analysis of variance (ANOVA) and then the differences between average values were evaluated using the LSD multiple comparisons test. At the first stage, results were tested according to their significance with ANOVA. The obtained average values were compared with the LSD test. In this process, the ANOVA test provides a statistical verification of whether or not the means of several groups are equal; it was used for comparing (testing) three or more means (groups or variables) for statistical significance. The different groups can be seen according to ANOVA results but it cannot be

Table I. Ranges of PET for different thermal perception classifications (TPCs) in the western/middle European temperature region (Matzarakis and Mayer, 1996).

\begin{tabular}{ccl}
\hline PET $\left({ }^{\circ} \mathrm{C}\right)$ & Thermal perception & Grade of physiological stress \\
\hline$<4$ & Very cold & Extreme cold stress \\
$4.1-8.0$ & Cold & Strong cold stress \\
$8.1-13.0$ & Cool & Moderate cold stress \\
$13.1-18.0$ & Slightly cool & Slight cold stress \\
$18.1-23.0$ & Comfortable & No thermal stress \\
$23.1-29.0$ & Slightly warm & Slight heat stress \\
$29.1-35.0$ & Warm & Moderate heat stress \\
$35.1-41.0$ & Hot & Strong heat stress \\
41.0 & Very hot & Extreme heat stress \\
\hline
\end{tabular}




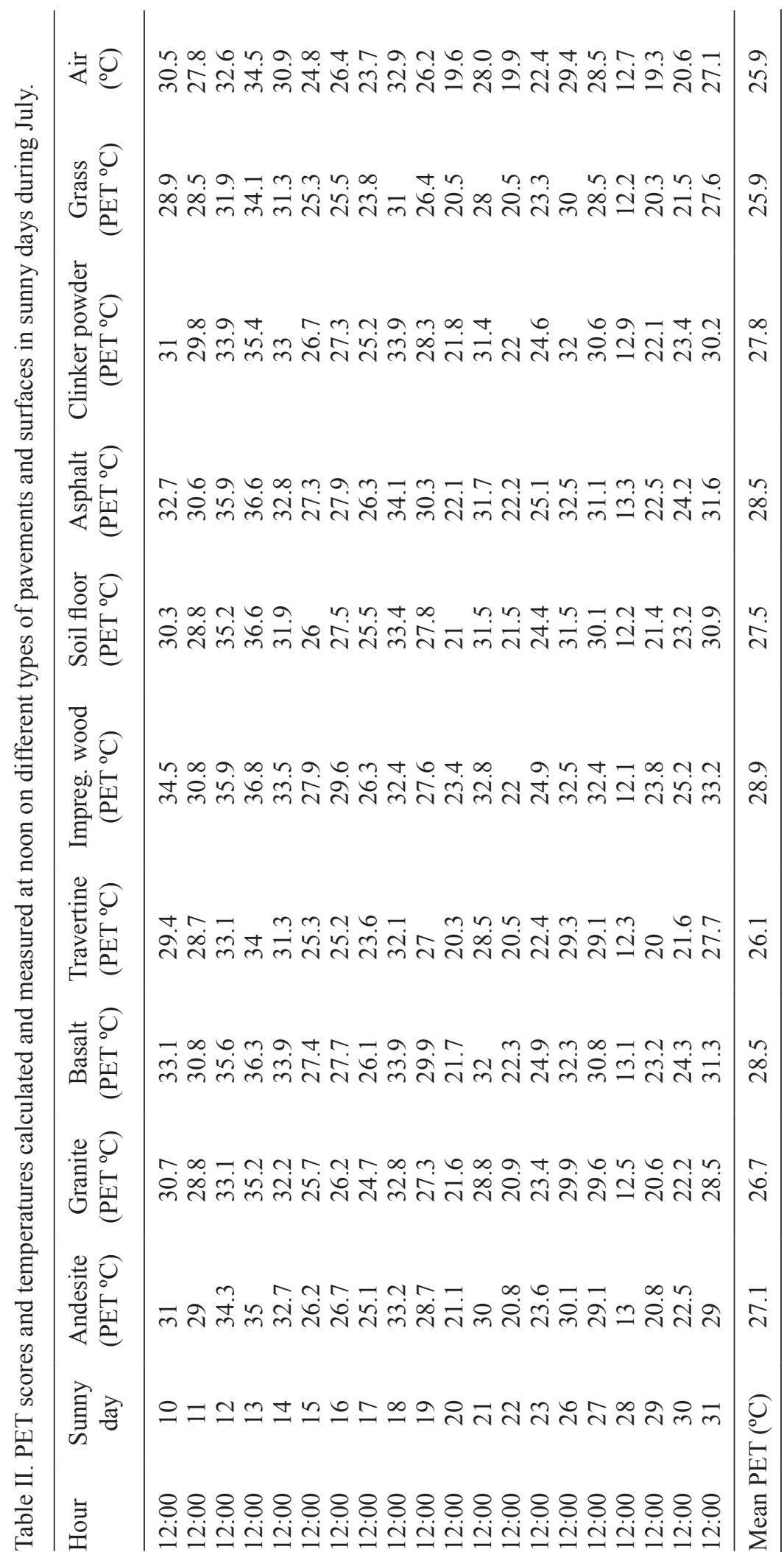




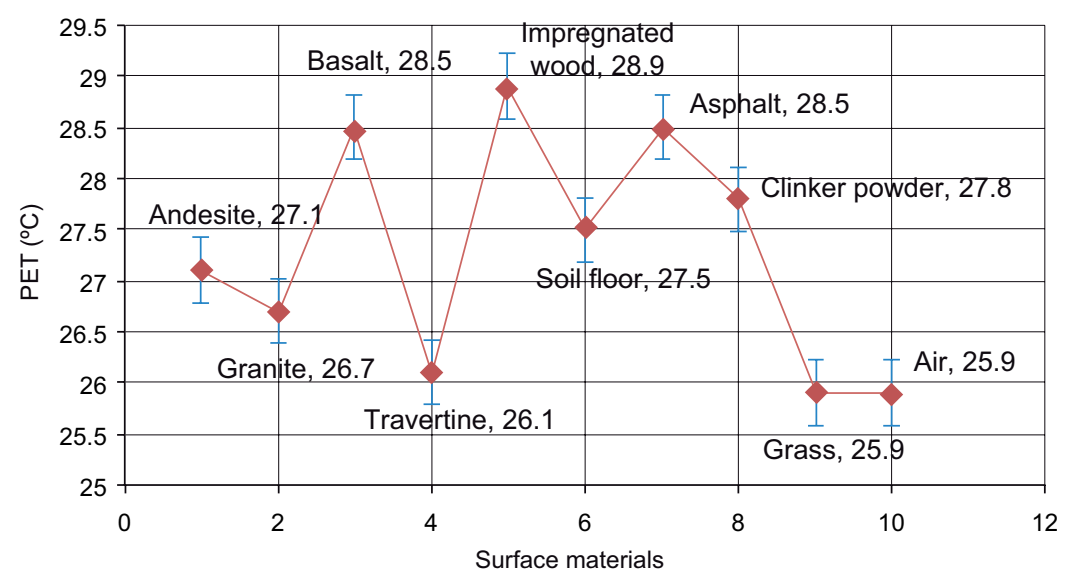

Fig. 4. Distribution of PET values for different surface materials.

said which group differs from the ANOVA test. In order to identify the different group in the test list, an LSD analysis is performed. LSD is used only when the null hypothesis is rejected as a result of the hypothesis test results. LSD enables direct comparisons between two means from two individual groups. Any difference larger than the LSD is considered a significant result.

\section{Findings}

According to the PET values calculated from measurements on different pavements and surfaces (Table II), grass $\left(25.9^{\circ} \mathrm{C}\right)$ and travertine $\left(26.1^{\circ} \mathrm{C}\right)$ rendered PET scores closest to the most comfortable range $\left(18.1-23.0^{\circ} \mathrm{C}\right)$, while the results for impregnated wood $\left(28.9^{\circ} \mathrm{C}\right)$, asphalt $\left(28.5^{\circ} \mathrm{C}\right)$, and basalt $\left(28.5^{\circ} \mathrm{C}\right)$ ranked within the slight heat stress zone. As it can be seen from Table II, there is a $2.5^{\circ} \mathrm{C}$ difference in terms of thermal comfort between grass and travertine, and impregnated wood, asphalt and basalt surfaces. This implies that the choice of grass and travertine to be used on surfaces in urban environments will improve thermal comfort levels at least in $2.5^{\circ} \mathrm{C}$.

Likewise, it is determined that there is a $3{ }^{\circ} \mathrm{C}$ difference between the PET scores of impregnated wood $\left(28.9^{\circ} \mathrm{C}\right.$, highest PET score $)$ and grass $\left(25.9^{\circ} \mathrm{C}\right.$, lowest PET score). The results for all of the different pavements and surfaces produced an ascending sort starting from the lowest to the highest PET score: grass $\left(25.9^{\circ} \mathrm{C}\right)$, travertine $\left(26.1^{\circ} \mathrm{C}\right)$, granite $\left(26.7^{\circ} \mathrm{C}\right)$, andesite $\left(27.1{ }^{\circ} \mathrm{C}\right)$, soil $\left(27.5^{\circ} \mathrm{C}\right)$, clinker powder (27.8), basalt $\left(28.5^{\circ} \mathrm{C}\right)$, asphalt $\left(28.5^{\circ} \mathrm{C}\right)$, and im- pregnated wood $\left(28.9^{\circ} \mathrm{C}\right)$ (Fig. 4$)$. As a result, all the measurements and analyses based on PET values and stress levels demonstrated that all tested pavements and surfaces fell into the group of slight heat stress (23.1-29.0 $\left.{ }^{\circ} \mathrm{C}\right)$. However, heat stresses for surfaces covered with grass, travertine, and cube granite are much closer to the comfortable range than impregnated wood, asphalt, and basalt.

As it can be seen from Figure 4, PET results for grass $\left(25.9^{\circ} \mathrm{C}\right)$ and impregnated wood $\left(28.9^{\circ} \mathrm{C}\right)$ show a difference of $3{ }^{\circ} \mathrm{C}$. The PET score for travertine $\left(26.1^{\circ} \mathrm{C}\right)$ is closest to that of $\operatorname{soil}\left(27.5^{\circ} \mathrm{C}\right)$. According to the TPC, all materials created heat stress. Materials with temperatures around $23^{\circ} \mathrm{C}$, which is the upper limit for comfortable thermal conditions, are the best ones to use in urban areas.

Table III shows the results of the statistical analyses. Thus, according to PET values, impregnated wood is categorized in group A, while asphalt and basalt are categorized in group $\mathrm{AB}$ because of their high scores. Clinker powder is classified in the $\mathrm{BC}$ group, while soil and andesite are grouped in the $\mathrm{CD}$ group according to their average values. On the other hand, granite is categorized in the DE group. Travertine and grass are differentiated from other groups as a result of their low PET values and are placed in the E group.

\section{Discussion}

Rayman Pro 2.1 was used in this study to simulate conditions for a 35 -yr-old man with a height of $1.75 \mathrm{~m}$ and a weight of $75 \mathrm{~kg}$, who is also in a standing 
Table III. Fisher's least significant difference (LSD) test results of PET scores $(\mathrm{p}<0.1)$.

\begin{tabular}{|c|c|c|c|c|c|c|}
\hline Level & & & & & & Least square mean \\
\hline Impregnated wood $\left(\mathrm{PET}^{\circ} \mathrm{C}\right)$ & A & & & & & $28.9^{\circ} \mathrm{C}$ \\
\hline Asphalt $\left(\mathrm{PET}^{\circ} \mathrm{C}\right)$ & A & $\mathrm{B}$ & & & & $28.5^{\circ} \mathrm{C}$ \\
\hline Basalt $\left(\mathrm{PET}^{\circ} \mathrm{C}\right)$ & A & $\mathrm{B}$ & & & & $28.5^{\circ} \mathrm{C}$ \\
\hline Clinker powder $\left(\mathrm{PET}^{\circ} \mathrm{C}\right)$ & & $\mathrm{B}$ & $\mathrm{C}$ & & & $27.8^{\circ} \mathrm{C}$ \\
\hline Soil $\left(\mathrm{PET}^{\circ} \mathrm{C}\right)$ & & & $\mathrm{C}$ & $\mathrm{D}$ & & $27.5^{\circ} \mathrm{C}$ \\
\hline Andesite $\left(\mathrm{PET}^{\circ} \mathrm{C}\right)$ & & & $\mathrm{C}$ & $\mathrm{D}$ & & $27.1^{\circ} \mathrm{C}$ \\
\hline Granite $\left(\mathrm{PET}^{\circ} \mathrm{C}\right)$ & & & & $\mathrm{D}$ & $\mathrm{E}$ & $26.7^{\circ} \mathrm{C}$ \\
\hline Travertine $\left(\mathrm{PET}{ }^{\circ} \mathrm{C}\right)$ & & & & & $\mathrm{E}$ & $26.1^{\circ} \mathrm{C}$ \\
\hline Grass $\left(\mathrm{PET}^{\circ} \mathrm{C}\right)$ & & & & & $\mathrm{E}$ & $25.9^{\circ} \mathrm{C}$ \\
\hline
\end{tabular}

$\mathrm{A}, \mathrm{B}, \mathrm{C}, \mathrm{D}$ and $\mathrm{E}$ show significant differences between de means at $\mathrm{p}<0.1$.

position and wears a jacket. However, the perception of climate conditions is modified by the variance of personal characteristics and clothing. Additionally, the TPC was developed according to the western/middle European climate zone. Therefore, the program should be developed for different thermal comfort zones, and a variety of personal characteristics and clothing can be added to the model. These elements can increase the use of the RayMan model. In the context of this study, the effects of different pavement and surface materials on climate were analyzed with the help of the RayMan model, which showed the absolute PET differences between them.

Lin et al. (2010) compared asphalt, interlocking blocks, concrete and grass, concluding that grass has better characteristics than the other materials and its PET score is lower. Therefore, the use of grass for decreasing the UHI effect is suggested. Also, in a similar study, Yilmaz et al. (2008) compared asphalt, soil and grass surfaces; their results showed that grass is cooler than asphalt in the hot period between July and September. Grass surfaces are 11.8 and $5.3{ }^{\circ} \mathrm{C}$ cooler than asphalt and soil on average. After the grass, travertine and granite materials produced temperatures and PET values in a comfortable range. They have better thermal properties and lower PET scores due to their light colors. As Radhi et al. (2014) stated, light or cool color pavements reduce the UHI effect. Accordingly, urban designs should be reconsidered for creating more green surfaces and using cool pavements (Ikechukwu, 2015).
As it can be seen in the LSD test, the differences between PET scores of the analyzed pavements and surfaces are significant. While impregnated wood is separated from other materials and classified in the warmer PET group, travertine and grass are statistically separated from the rest and located in the colder PET group. Plants are in the cool group due to their transpiration and the shadow and albedo effects on the environment in which they are located. However, travertine was placed in the same group and has the same effect than plants. This is an important finding for the determination of surfaces and pavements in the urban design process. It will help related disciplines such as architecture, urban planning and landscape architecture. Similarly, impregnated wood obtained warmer scores than other materials, even asphalt, which is also an important result for the use of impregnated wood in urban environment, especially in cities with warm climates.

\section{Conclusions}

The findings of this study indicate that the difference between the highest and lowest PET scores associated with impregnated wood $\left(28.9^{\circ} \mathrm{C}\right)$ and grass $\left(25.9^{\circ} \mathrm{C}\right)$ was $3.0^{\circ} \mathrm{C}$. When the PET scores were arranged from lowest to highest, the following order was obtained: grass $\left(25.9^{\circ} \mathrm{C}\right)$, travertine $\left(26.1^{\circ} \mathrm{C}\right)$, granite $\left(26.7^{\circ} \mathrm{C}\right)$, andesite $\left(27.1^{\circ} \mathrm{C}\right)$, soil $\left(27.5^{\circ} \mathrm{C}\right)$, clinker powder $(27.8)$, basalt $\left(28.5^{\circ} \mathrm{C}\right)$, asphalt $\left(28.5^{\circ} \mathrm{C}\right)$, and impregnated wood $\left(28.9^{\circ} \mathrm{C}\right)$. In order to reduce the UHIs and to provide comfortable living conditions, preference should be given to grass and travertine as surface materials. In fact, these two can 
be combined in the design of pavements. They also will be suitable for winter conditions by preventing slippage and improving drainage.

The PET scores obtained from different types of pavements and surfaces were subjected to statistical analysis and the results were found to be significantly different $(p<0.01)$. According to the comparative test results shown in Table III, the lowest PET scores were obtained for grass and travertine and they were classified statistically in the same group. The highest PET score was obtained for impregnated wood. The most significant statistical difference was found between the groups of impregnated wood, and grass and travertine.

Finally, according to our results, the most appropriate materials for mitigation of the UHI and human comfort during the summer are grass, travertine and granite. Impregnated wood, asphalt and basalt should be used only in a limited manner within the design process, due to their characteristic high absorption of heat. The limited use of these materials is crucial for mitigating the UHI effects.

This study is useful to landscape and urban design professionals, whose commitment to urban environment reflects the need of livable cities and high thermal comfort levels in outdoor environments in order to increase the quality of life of human beings in urban areas. The results allow designers to select the most suitable surface materials for urban areas according to their thermal effects. Furthermore, urban and landscape designers may determine the effects of surface materials on human thermal comfort for every season. Therefore, designers can evaluate the adjustment possibilities of different surface materials on urban areas in terms of climatic conditions and contribute to the bioclimatic design of urban environment. They can also determine the best uses for materials according to their thermal behavior.

High-resolution thermal cameras and remote sensing methods need to be integrated in order to get more accurate results for improving outdoor thermal comfort. Additionally, this study should be reproduced in different seasons for those materials. The creation of climatic comfort in cities is a challenging task for urban and landscape designers. With this study, it is expected that the knowledge of the effects of surface materials on urban thermal comfort will be integrated to urban and landscape design practices.

\section{Acknowledgments}

We would like to thank the Turkish State Meteorological Service (DMI) for sharing their data free of charges, as well as the Ataturk University (BAP Project No. 20121495).

\section{References}

Asaeda T., V.T. Ca and W. Akio, 1996. Heat storage of pavement and its effect on the lower atmosphere. Atmos. Environ. 30, 413-427.

doi: 10.1016/1352-2310(94)00140-5

Aguiar A. C., K. French and L. A. Chisholm, 2014. A comparison of the ameliorating effects of native and exotic street trees on surface heat retention at dusk. Urban Climate 10, 56-62. doi: 10.1016/j.uclim.2014.09.004

Bobes-Jesus V., P. Pascual-Muñoz, D. Castro-Fresno and J. Rodriguez-Hernandez, 2013. Asphalt solar collectors: a literature review. Appl. Energ. 102, 962-970.

doi: 10.1016/j.apenergy.2012.08.050

Cartalis C., A. Synodinou, M. Proedrou, A. Tsangrasouli and M. Santamouri, 2001. Modifications in energy demand in urban areas as a result of climate changes: an assessment for the Southeast Mediterranean region. Energ. Convers. Manage. 42, 1647-1656. doi: 10.1016/S0196-8904(00)00156-4

Correa E.N., M.A. Ruiz, A. Cantón and G. Lesino, 2012. Thermal comfort in forested urban canyons of low building density. An assessment for the city of Mendoza. Build. Environ. 58, 219-230.

doi: 10.1016/j.buildenv.2012.06.007

Di Norcia V., 2008. Global warming is man-made: Key points the International Panel on Climate Change 2007 report. In: Hard like water. Ethics in business. Oxford University Press, UK, 1-4.

Gulyás Á. and A. Matzarakis, 2009. Seasonal and spatial distribution of physiologically equivalent temperature (PET) index in Hungary. Quart. J. Hungarian Met. Serv. 113, 221-231.

Irmak M.A. and S. Yilmaz, 2015. Effects of different floor covering materials on thermal comfort in landscape design studies. ICUC9 - 9th International Conference on Urban Climate jointly with the 12th Symposium on the Urban Environment, 20-24 July, Oral Presentation, Toulouse, France.

Ikechukwu E., 2015. The effects of road and other pavement materials on urban heat island (a case study of Port Harcourt city). J. Environ. Prot. 6, 328-340.

doi: $10.4236 /$ jep.2015.64033 
Jongtanom Y., C. Kositanont and S. Baulert, 2011. Temporal variations of urban heat island intensity in three major cities, Thailand. Mod. Appl. Sci. 5, 105-110. doi: 10.5539/mas.v5n5p105

Ketterer K. and A. Matzarakis, 2014. Human biometeorological assessment of heat stress reduction by replanning measures in Stuttgart, Germany. Landscape Urban Plan. 122, 78- 88. doi: 10.1016/j.landurbplan.2013.11.003

Kottek M., J. Grieser, C. Beck, B. Rudolf and F. Rubel, 2006. World map of the Köppen-Geiger climate classification updated. Meteorol. Z. 15, 259-263. doi: 10.1127/0941-2948/2006/0130

Lagouarde J.-P., A. Henon, M. Irvine, J. Voog, G. Pigeon, P. Moreau, V. Masson and P. Mestayer, 2012. Experimental characterization and modelling of the nighttime directional anisotropy of thermal infrared measurements over an urban area: Case study of Toulouse (France). Remote Sens. Environ. 117, 19-33.

doi: 10.1016/j.rse.2011.06.022

Lenzholzer S. and R.D. Brown, 2013. Climate-responsive landscape architecture design education. J. Clean. Prod. 61, 89-99. doi: 10.1016/j.jclepro.2012.12.038

Leuzinger S., R. Vogt and C. Körner, 2010. Tree surface temperature in an urban environment. Agr. Forest Meteorol. 150, 56-62. doi: 10.1016/j.agrformet.2009.08.006

Lin T.P., A. Matzarakis, R.-L. Hwang and Y.-C. Huang, 2010. Effect of pavements albedo on long-term outdoor thermal comfort. In: Proceedings of the 7th Conference on Biometeorology (A. Matzarakis, H. Mayer and F.-M. Chmielewski, Eds.). Freiburg, Germany, April.

Lin T.P., R. de Dear and R.L. Hwang, 2011. Effect of thermal adaptation on seasonal outdoor thermal comfort. Int. J. Climatol. 31, 302-312. doi: 10.1002/joc. 2120

Matzarakis A. and H. Mayer, 1996. Another kind of environmental stress: Thermal stress. WHO Collaborating Centre for Air Quality Management and Air Pollution Control. Newsletter 18, 7-10.

Matzarakis A., F. Rutz and H. Mayer, 2007. Modelling radiation fluxes in simple and complex environments Application of the RayMan model. Int. J. Biometeorol. 51, 323-334. doi: 10.1007/s00484-006-0061-8

Matzarakis A., F. Rutz and H. Mayer, 2010. Modelling radiation fluxes in simple and complex environments: Basics of the RayMan model. Int. J. Biometeorol. 54, 131-139.

doi: 10.1007/s00484-009-0261-0
Memon R.A., D.Y.C. Leung and L. Chunho, 2008. A review on the generation, determination and mitigation of urban heat island. J. Environ. Sci. (China) 20, 120-128. doi: 10.1016/S1001-0742(08)60019-4

Millstein D. and S. Menon, 2011. Regional climate consequences of large-scale cool roof and photovoltaic array deployment. Environ. Res. Lett. 6, 034001. doi: $10.1088 / 1748-9326 / 6 / 3 / 034001$

Oke T.R., D.G. Johnson, D.G. Steyn and L.D. Watson, 1991. Simulation of surface urban heat island under 'ideal' conditions at night - Part 2: diagnosis and causation. Bound. Layer Meteorol. 56, 339-358. doi: 10.1007/BF00119211

Radhi H., E. Assem and S. Shaples, 2014. On the colours and properties of building surface materials to mitigate urban heat islands in highly productive solar regions. Build. Environ. 72, 162-172. doi: 10.1016/j.buildenv.2013.11.005

Rodríguez Algeciras J.A., L. Gómez Consuegra and A. Matzarakis A., 2016. Spatial-temporal study on the effects of urban street configurations on human thermal comfort in the world heritage city of Camagüey-Cuba. Build. Environ. 101, 85-101. doi: 10.1016/j.buildenv.2016.02.026

Rupp R.F., N. G. Vásquez and R. Lamberts, 2015. A review of human thermal comfort in the built environment. Energ. Build. 105, 178-205. doi: 10.1016/j.enbuild.2015.07.047

Santamouris M., A. Synnefa and T. Karlessi, 2011. Using advanced cool materials in the urban built environment to mitigate heat islands and improve thermal comfort conditions. Sol. Energy 85, 3085-3102.

doi: 10.1016/j.solener.2010.12.023

Santamouris M., 2013. Using cool pavements as a mitigation strategy to fight urban heat island - A review of the actual developments. Renew. Sustain. Energ. Rev. 26, 224-240. doi: 10.1016/j.rser.2013.05.047

Synnefa A., M. Santamouris and K. Apostolakis, 2007. On the development, optical properties and thermal performance of cool colored coatings for the urban environment. Solar Energ. 81, 488-497. doi: 10.1016/j.solener.2006.08.005

Takebayashi H. and M. Moriyama, 2009. Study on the urban heat island mitigation effect achieved by converting to grass-covered parking. Sol. Energy. 83-8, 1211-1223.

doi: 10.1016/j.solener.2009.01.019 
UN, 2012. World Urbanization Prospects: The 2011 Revision. United Nations, Department of Economic and Social Affairs, Population Division.

Unger J., 1999. Comparisons of urban and rural bioclimatological conditions in the case of a Central-European city. Int. J. Biometeorol. 43, 139-144.

doi: $10.1007 / \mathrm{s} 004840050$

Yilmaz S., S. Toy, M. A. Irmak and H. Yilmaz, 2007a. Determination of climatic differences in three different land uses in the city of Erzurum, Turkey. Build. Environ. 42, 1604-1612.

doi: 10.1016/j.buildenv.2006.01.017

Yilmaz S., S. Toy and H. Yilmaz, 2007b. Human thermal comfort over three different land surfaces during summer in the City of Erzurum, Turkey. Atmósfera 20, 289-297.
Yilmaz H., S. Toy, M.A. Irmak, S. Yilmaz and Y. Bulut, 2008. Determination of temperature differences between asphalt concrete, soil and grass surfaces of the City of Erzurum, Turkey. Atmósfera 21, 135-146.

Yilmaz S., M.A. Irmak and A. Matzarakis, 2013. The importance of thermal comfort in different elevation for city planning. Global NEST Journal 15, 408-420.

Yilmaz H., S. Yilmaz, M. Yavas, E. Mutlu and A. Koç, 2016. Climate-sensitive pavement modelling for pedestrian ways. 4th International Conference on Countermeasures to Urban Heat Island, 30-31 May and 1 June. National University of Singapore. 